\title{
Quality of Working Life and Nutritional Status in a Sample of Industrial Workers
}

\author{
Mohammad Didar Hossain and Luthfor Ahmed*
}

Institute of Nutrition and Food Science, University of Dhaka, Dhaka-1000

\begin{abstract}
Linkages between diet habits and the quality of working life is a new phenomenon and continue to surface on many fronts. Evidences are there that dietary and non-dietary components are capable of influencing workplace activities, work life, and thereby work performance and productivity. This cross sectional study examined the quality of working life (QWL) and nutritional status of a representative group of sixty-five male workers in an industrial setting. Quality of work life index was measured by administering the scale developed by Yousuf. Nutritional status was assessed by 24-hr food recalls and anthropometric measures. The measured score for QWL ranged 185.0-212.0 with a mean of $193.83 \pm 5.57$, which is about seventy three percent of the totals, suggestive of 'medium' quality of QWL. Older with longer job experience, having higher salary and poorly educated workers showed significantly higher QWL score $(p<0.01)$. They seem content with their work life and are satisfied in their job. Food and nutrient intakes were inadequate both in quality and quantity. Mean calorie intake was $2196 \pm 400 \mathrm{kcal}$ (79\% RDI). Cereals and roots/tubers were the major contributor of energy (65\% of the total) and protein consumed. Intakes of egg, meat and milk products were very poor. About twenty percent of the workers measured undernourished (BMI<18.5). Moderate level of QWL compounded with poor and inadequate nourishment would certainly compromise work performance and thereby contribute to low productivity.
\end{abstract}

Key Words: Quality of working life (QWL), shift workers, job satisfaction, food consumption pattern, nutritional status.

\section{Introduction}

Bangladesh is a small impoverished country in the South Asian green belt with over 140 million people. In recent time, the country is transforming, though with a slow pace, from largely agrarian underdeveloped economics into dynamic industrial country. The contributions of industry and agriculture sectors in the country's GDP in 2004/2005 were 28 percent and 22 percent respectively ${ }^{1}$. Industries (manufacturing sector) expanded at an average rate of 6.44 percent per annum throughout the years of FY 1972-2005. Eleven percent of the country's labour force is engaged in industrial sector. The workers are the driving force of the national economy, and thus evaluation of their working lives, work-

Bangladesh Journal of Nutrition. Vol 18-19, December 2005-2006. Institute of Nutrition and Food Science, University of Dhaka-1000, Bangladesh.

${ }^{*}$ Author for correspondence 
tasks and identification of work exposure, their health and life style, living environment etc. calls for. Popular human relations view is that a satisfied worker is a more productive worker. 'Quality of working life' is a generic phrase that covers a person's feeling about every dimension of work including economic rewards and benefits, security, working conditions, organizational and interpersonal relationships, and it's intrinsic meaning in a person's life ${ }^{2}$. It refers to a relationship between the worker and work environment. Human health, disease, productivity, socioeconomic development, quality of life index etc. are directly related and dependent on nutrition. Poor nutrition underlies workplace issues like morale, safety, productivity and long term health of the workers and nation. There is little doubt that nutrition and health are intimately linked with physical activity and productivity. Evidences are there that dietary and non-dietary components are capable of influencing workplace activities, work life, and thereby work performance and productivity.

Therefore, the present study was conducted with the major objective of investigating quality of working life narratives of the workers in an industrial setting and to document their food intake and health status.

\section{Materials and Methods}

This cross sectional study was conducted on a total of sixty five individuals selected by simple random sampling from the study population of 414 . The setting of the study was Tejgaon industrial area in the capital city of Dhaka.

\section{Sample selection and sample size estimation}

The nature of the study (behavioural research) calls for to follow the 'rule of thumb' allowing us to draw a sample of $10 \%$ of the total population for scientific representation. Therefore we needed only 42 subjects, but for better representation sixty-five workers ( 30 from the morning shift and 35 from the evening shift) was enrolled. Consent was obtained from the factory authority and the worker. Randomization was done from among the workers of both the shifts (morning and evening) that consented to take part in the study.

\section{Variables and measurements}

A set of structured questionnaire were administered to the selected participants to obtain general information of the workers and to assess their quality of work life and food intake. The questionnaire was validated by a pilot study before starting the main research. To do this, the questionnaire was distributed to 15 individuals with the same characteristics and from the same area as main study participants. After assessment and evaluation of the research results of this pilot, the main research started.

Quality of working life. The instrument (questionnaire) used in the present study was developed by Yousuf ${ }^{3}$. The questionnaire consisted of 27 -items. Responses were elicited on 11 point scale ranging from worst possible work life (score 0) to the Best possible work life (score 10). The items on perceived growth, perceived mastery, perceived involvement, perceived control-in-contexts, and perceived stimulation-in-contexts, were 
recorded on 5-point Likert type scales. Likert scoring system was followed for both positive and negative items on workers attitude on the variables of the nature of the present job, opportunities for promotion, present pay, people on present job and supervision on present job. These were measured through an adjective checklist having binary (Yes/No) responses. For minimizing the effect of response set, some of the items were negatively worded. The total weighted score for QWL is 265 , and was classified into three groups- 'Good' (more than $80 \%$ ), 'Medium' (60-80\%) and 'Poor' (less than $60 \%)$.

Diet history. Dietary intake data on the type and amount of food during the previous 24hours were collected by interviewing the workers. Values for energy and nutrients were computed from local Food Composition Tables ${ }^{4}$.

Anthropometry. The heights and weights of the workers were measured using a wooden stadiometer and pre calibrated digital weighing scale (SECA). The measurements were taken single handedly by a trained person to avoid inter-observer errors. The subjects wore light clothes and no shoes during measurement. Height was measured to the nearest $0.1 \mathrm{~cm}$ and weight was measured to the nearest $0.1 \mathrm{~kg}$. The weight $(\mathrm{kg})$ was then divided by the height $\left(\mathrm{m}^{2}\right)$ to calculate the Body mass index (BMI), which is considered a good indicator for evaluating adult nutritional status, because it is inexpensive, non-invasive and reliable.

All the participants were interviewed personally respecting their privacy. The respondents were fully assured of the fact that their responses would be kept strictly confidential and would be utilized only for research purposes.

Data Analyses. The data were entered and processed by SPSS release 12.0 and ANTHRO software packages. Paired comparisons were performed by student $t$-test and analysis of variance. Chi-square test was performed to test the difference in proportions of categorical values. Pearson product moment correlation was used to estimate the correlation between the items. Differences were considered statistically significant when $p$ value was less than 0.05 .

\section{Results \\ Characteristics of the study subjects}

The characteristics of the study population are shown in Table 1. The mean age and experience of the workers were $35 \pm 11$ years and $16 \pm 11$ years respectively. About half of the observed work force was found working more than 10 years but less than 20 years. Forty six percent of them work in the morning shift and fifty four percent in the evening shift. Of them $52 \%$ are either illiterate or had primary level and $48 \%$ had secondary level of education. 
Bangladesh J. Nutr. Vol. 18-19, December 2005-2006

Table 1: Study group characteristics $(n=65)$

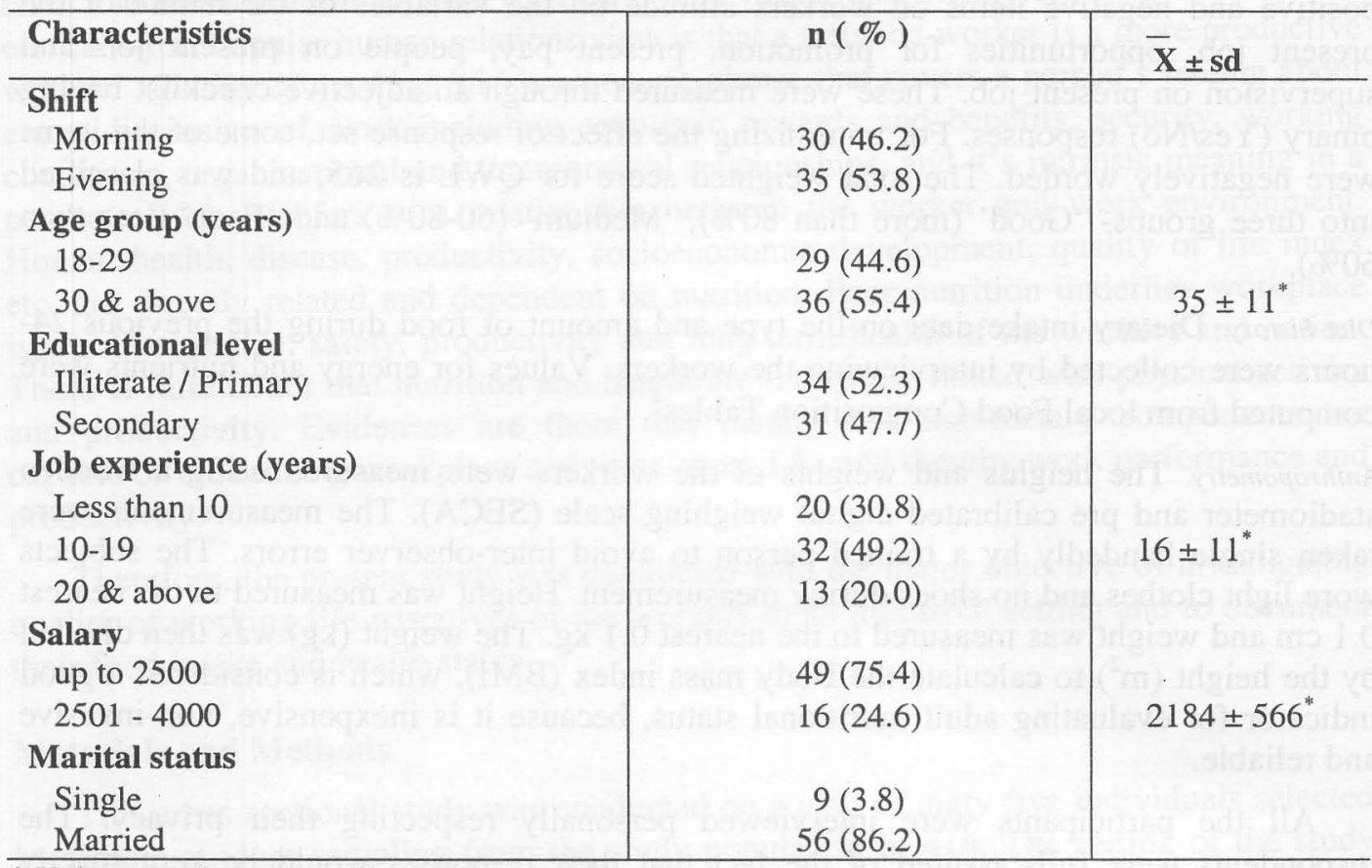

* Values are the mean with standard deviation

General food pattern

Reported consumption of food items or food groups are presented in Table 2. Overall, the food patterns of the workers were based on rice, roots and tubers, and vegetables i.e., on plant foods. Consumption of egg, meat pulses and milk/milk products were poor.

Table 2: Mean per capita food intake (in gram)

\begin{tabular}{c|c|c|c|c|c|c|c|c|c|c|c|c|c}
\hline $\begin{array}{c}\text { Food } \\
\text { items }\end{array}$ & $\begin{array}{c}\text { Cereal } \\
\text { (rice, } \\
\text { wheat) }\end{array}$ & Rice & $\begin{array}{c}\text { Root } \\
\text { and } \\
\text { tubers }\end{array}$ & Sugar & $\begin{array}{c}\text { Pulse } \\
\text { and } \\
\text { nut }\end{array}$ & $\begin{array}{c}\text { Vegeta } \\
\text { bles }\end{array}$ & Fruits & Meat & Egg & Fish & $\begin{array}{c}\text { Milk/Milk } \\
\text { products }\end{array}$ & $\begin{array}{c}\text { Fats and } \\
\text { oil }\end{array}$ & $\begin{array}{c}\text { Misc. } \\
\text { Mean }\end{array}$ \\
$\begin{array}{c}439 \\
\pm 92\end{array}$ & $\begin{array}{c}403 \\
\pm 104\end{array}$ & $\begin{array}{c}174 \\
\pm 130\end{array}$ & $\begin{array}{c}5 \\
\pm 5\end{array}$ & $\begin{array}{c}27 \\
\pm 23\end{array}$ & $\begin{array}{c}154 \\
\pm 157\end{array}$ & $\begin{array}{c}23 \\
\pm 48\end{array}$ & $\begin{array}{c}12 \\
\pm 39\end{array}$ & $\begin{array}{c}6 \\
\pm 14\end{array}$ & $\begin{array}{c}54 \\
\pm 77\end{array}$ & $\begin{array}{c}14 \\
\pm 35\end{array}$ & $\begin{array}{c}18 \\
\pm 4\end{array}$ & $\begin{array}{c}14 \\
\pm 25\end{array}$ \\
\hline
\end{tabular}

\section{Calorie and nutrient intake}

In the Table 3 the mean intakes of energy and nutrient, their corresponding RDI and the percent fulfillment to the requirement are shown. It was found that the mean energy intake was $2196 \pm 400 \mathrm{k} \mathrm{cal} /$ day showing signs of energy deficiency, fulfilling nearly $80 \%$ of the demanded requirement. Rice is accounted for $65 \%$ of total energy. Rice also contributed the largest amount of protein, which is of low bio-available value for protein activity. Protein intake was more than the requirement. Contribution of fat and riboflavin in the daily intake were also very poor, contributing only 30 and 34 percent of their 
requirement. Intakes of vitamin A and iron were found to be two-thirds of their required level. The mean intakes of energy and nutrients by the observed industrial workers working at different shifts are shown in Table 4 . The mean difference was not significant between the groups for any of the nutrients excepting thiamine and vitamin-C. Higher intakes of these two micronutrients were observed among the workers in the morning shift than their counterparts $(p<0.00)$.

Table 3: Energy and nutrient daily intakes and percent RDI

\begin{tabular}{l|c|c|c}
\hline Energy and Nutrients & Mean (SD) & RDI* & Percent of RDI \\
\hline Energy (kcal) & $2196 \pm 400$ & 2788 & 78.77 \\
Protein (g) & $58 \pm 23$ & 53.7 & 109.43 \\
Fat (g) & $28 \pm 7$ & 92.0 & 30.44 \\
Carbohydrate (g) & $431 \pm 86$ & - & - \\
Calcium (mg) & $552 \pm 778$ & 450 & 122.67 \\
Iron (mg) & $14 \pm 9$ & 18 & 77.78 \\
Vit-A (IU) & $1415 \pm 2628$ & 2000 & 70.75 \\
Thiamine (mg) & $1.38 \pm 0.33$ & 1.39 & 99.28 \\
Riboflavin (mg) & $0.57 \pm 0.32$ & 1.67 & 34.13 \\
Niacin (mg) & $21 \pm 5$ & 19.0 & 110.52 \\
Vit-C (mg) & $57 \pm 40$ & 50.0 & 114.00 \\
Zinc (mg) & $9 \pm 3$ & - & - \\
\hline
\end{tabular}

* Source: INFS-BNNS, 1995-96

Table 4: Per capita energy and nutrient intake (mean \pm SD) by shift

\begin{tabular}{l|c|c|c}
\hline \multirow{2}{*}{ Energy and Nutrients } & \multicolumn{2}{|c|}{ Shift } & \multirow{2}{*}{$p$-value } \\
\cline { 2 - 3 } & Morning & Evening & .16 \\
\hline Energy (kcal) & $2271 \pm 405$ & $2131 \pm 391$ & .97 \\
Protein (g) & $58 \pm 14$ & $58 \pm 29$ & .31 \\
Fat (g) & $29 \pm 7$ & $27 \pm 7$ & .12 \\
Carbohydrate (g) & $449 \pm 93$ & $416 \pm 78$ & .17 \\
Calcium (mg) & $408 \pm 268$ & $675 \pm 1023$ & .92 \\
Iron (mg) & $14 \pm 6$ & $14 \pm 11$ & .80 \\
Vit-A (IU) & $144 \pm 241$ & $131 \pm 183$ & .19 \\
Carotene ( $\mu \mathrm{g})$ & $4879 \pm 8641$ & $10061 \pm 19745$ & .00 \\
Thiamine (mg) & $1.52 \pm 0.30$ & $1.26 \pm 0.30$ & .20 \\
Riboflavin (mg) & $0.52 \pm 0.18$ & $0.62 \pm 0.39$ & .52 \\
Niacin (mg) & $22 \pm 4$ & $21 \pm 6$ & .00 \\
Vit-C (mg) & $73 \pm 48$ & $42 \pm 24$ & .81 \\
Zinc (mg) & $9 \pm 2$ & $9 \pm 4$ & \\
\hline
\end{tabular}

\section{Anthropometry}

The mean values for weight, height and BMI are presented in Table 5. Seventy-one percent workers were of normal weight by their BMI score. Twenty percent of them were under weight (CED grade-I) and $9 \%$ was over weight. 


\section{Quality of working life}

Table 6 presents the results for clusters of quality of working life. The mean total score attained by the surveyed workers was $193.83 \pm 5.57$ with a range of $185.0-212.0$. The observed mean score is considered as 'average' ( $73 \%$ of the total) as per grading. No significant group difference could be elicited between the shifts (data not shown). Level of satisfaction on each of the eleven items could be understandable by their scoring against weighted value. Dissatisfaction or negative responses for the clusters like work life, present pay, promotion, control-in-context and stimulation-in-context were referred more. The recorded score for these clusters ranged between $42 \%$ and $68 \%$ of the weighted value. The clusters drawing most positive responses are growth, people on present job and supervision on present job.

Table 5: Physical characteristics of the subjects

\begin{tabular}{l|ccc}
\hline & Mean \pm SD & \\
\hline Weight $(\mathrm{kg})$ & $56.01 \pm 7.22$ & \\
Height $(\mathrm{cm})$ & $164.20 \pm 5.74$ & & \\
BMI $\left(\mathrm{kg} \mathrm{m}^{-2}\right)$ & $20.80 \pm 2.73$ & $<18.5$ & $13(20)^{*}$ \\
& & $18.5-24.9$ & $46(71)$ \\
& & $>25.0$ & $6(9)$ \\
\hline
\end{tabular}

*Figure in parentheses are percentage

Table 6: Mean QWL scores and percentage of weighted value of the subjects

\begin{tabular}{l|c|c|c}
\hline A priori clusters & QWL score & Weighted value & $\begin{array}{c}\text { Percent of } \\
\text { reported score }\end{array}$ \\
\hline Work life & $27.8 \pm 5.6$ & 55 & 50.54 \\
Perceived Growth & $19.9 \pm 0.5$ & 20 & 99.50 \\
Perceived Mastery & $16.2 \pm 1.0$ & 20 & 81.00 \\
Perceived Involvement & $7.6 \pm 0.8$ & 10 & 76.00 \\
Perceived Control-in-Contexts & $6.0 \pm 0.0$ & 10 & 60.00 \\
Perceived Stimulation-in-Context & $4.2 \pm 0.5$ & 10 & 42.00 \\
Work in Present Job & $26.8 \pm 0.7$ & 36 & 74.45 \\
Opportunities for Promotion & $10.1 \pm 0.3$ & 16 & 63.12 \\
Present Pay & $9.0 \pm 0.0$ & 16 & 56.25 \\
People on Your Present Job & $35.0 \pm 0.0$ & 36 & 97.22 \\
Supervision on present job & $31.2 \pm 0.5$ & 36 & 86.67 \\
\hline Total score & $\mathbf{1 9 3 . 8 3 \pm 5 . 5 7}(\mathbf{1 8 5 . 0 - 2 1 2 . 0 )}$ \\
\hline
\end{tabular}


Table 7: Association of the working place inventory scores of participants by sociodemographic characteristics

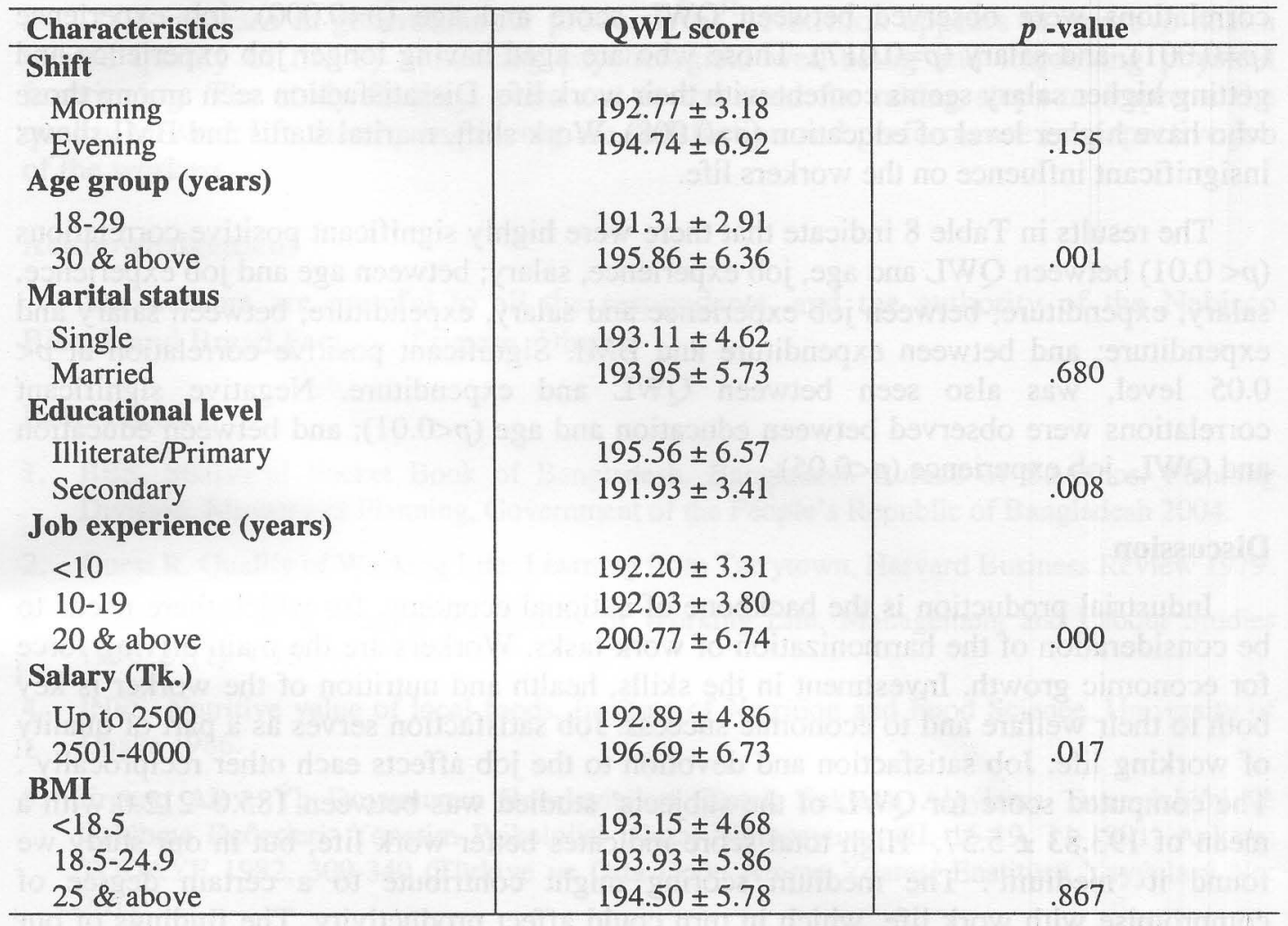

Table 8: Correlation matrix for QWL, age, education, marital status, experience, salary, expenditure and BMI

\begin{tabular}{|c|c|c|c|c|c|c|c|c|}
\hline 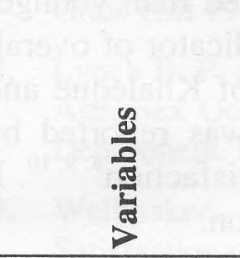 & $\frac{1}{2}$ & $\underset{<}{\infty}$ & 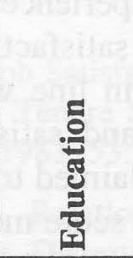 & $\frac{\frac{n}{3}}{\frac{\pi}{5}}$ & 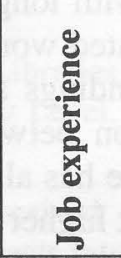 & $\frac{\vec{E}}{\tilde{D}}$ & 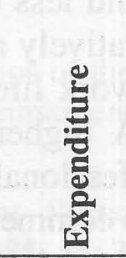 & $\sum_{\infty}^{B}$ \\
\hline QWL & 1.000 & $.729 * *$ & $-.303 *$ & .052 & $.631 * *$ & $.429 * *$ & $.295 *$ & .189 \\
\hline Age & & 1.000 & $-.338 * *$ & .196 & $.870 * *$ & $.516 * *$ & $.483 * *$ & .192 \\
\hline Education & & & 1.000 & -.053 & $-.307 *$ & -.104 & -.074 & .112 \\
\hline Marital status & & & & 1.000 & .130 & .110 & .061 & .161 \\
\hline Job experience & & & & & 1.000 & $.629 * *$ & $.479 * *$ & .102 \\
\hline Salary & & & & & & 1.000 & $.479 * *$ & .219 \\
\hline Expenditure & & & & & & & 1.000 & $.376 * *$ \\
\hline BMI & & & & & & & & 1.000 \\
\hline
\end{tabular}

** Correlation is significant at the 0.01 level (2-tailed)

* Correlation is significant at the 0.05 level (2-tailed) 
Table 7 examines the attained QWL score of the observed subjects by their sociodemographic characteristics, which could affect their work life. Positive significant correlations were observed between QWL score and age $(p=0.000)$, job experience $(p=0.001)$, and salary $(p=0.017)$. Those who are aged having longer job experience and getting higher salary seems content with their work life. Dissatisfaction seen among those who have higher level of education $(p=0.008)$. Work shift, marital status and BMI shows insignificant influence on the workers life.

The results in Table 8 indicate that there were highly significant positive correlations $(p<0.01)$ between QWL and age, job experience, salary; between age and job experience, salary, expenditure; between job experience and salary, expenditure; between salary and expenditure; and between expenditure and BMI. Significant positive correlation at $p<$ 0.05 level, was also seen between QWL and expenditure. Negative significant correlations were observed between education and age $(p<0.01)$; and between education and QWL, job experience $(p<0.05)$.

\section{Discussion}

Industrial production is the backbone of national economy, for which there needs to be consideration of the harmonization of work-tasks. Workers are the main driving force for economic growth. Investment in the skills, health and nutrition of the worker is key both to their welfare and to economic success. Job satisfaction serves as a part of quality of working life. Job satisfaction and devotion to the job affects each other reciprocally. The computed score for QWL of the subjects' studied was between 185.0-212.0 with a mean of $193.83 \pm 5.57$. High total score indicates better work life, but in our study we found it 'medium'. The medium scoring might contribute to a certain degree of compromise with work life, which in turn could affect productivity. The findings of our study are consistent with other studies that have examined the workers' life style with their work life. In this study the variables-age $(p=.001)$, income $(p=.017)$, qualification $(p=.008)$ and experience $(p=.000)$ were seen to influence different dimensions of QWL. The older and less educated with longer job experience are more satisfied than younger and comparatively more educated workers. Job satisfaction is a good indicator of overall quality of work life. These findings are more in line with the results of Khaleque and Rahman $^{6}$. A higher association between age and satisfaction in job was reported by Davis $^{7}$. Professional experience has also been claimed to increase job satisfaction ${ }^{8,9}{ }^{10}$. It is worthy to comment here that higher the QWL score more the satisfaction.

Adequate nutrition creates positive outcomes and improves quality of life. We did attempt to obtain reliable measures of the subjects' nutritional status in reference to dietary and anthropometric indicators. Access to healthy food was not noticed. Food and nutrient quality of the surveyed workers was inadequate both in quantity and quality. The observed mean per capita energy intake was $22 \%$ less than the required level. Moreover, overwhelming presence of cereals in their diet put the nutrient quality of the meal poorer. Mention must be made here that work shift did not make any difference either for the food intake or QWL between the groups. Anthropometrically $20 \%$ of the observed workers were found underweight by their BMI values. 
Nutrition and activity are two of the essential conditions of daily living. To our knowledge, it has been reported that in developing countries $1 \% \mathrm{kcal}$ increase can result in $2.27 \%$ increase in general labour productivity ${ }^{4}$. Nutrition appears to improve health related quality of life by enhancing psychological well-being and improving physical functioning. The study findings point out to the need for taking steps to improve the quality of work life thereby improving the satisfaction and performance in respective job of the workers.

\section{Acknowledgement}

The authors are grateful to all the respondents, and the authority of the Nabisco Biscuit and Bread Factory, Tejgaon, Dhaka.

\section{References}

1. BBS. Statistical Pocket Book of Bangladesh. Bangladesh Bureau of Statistics, Planning Division, Ministry of Planning, Government of the People's Republic of Bangladesh 2004.

2. Guest R. Quality of Working Life: Learning from Tarrytown, Harvard Business Review 1979.

3. Yousuf S.M.A. Evaluating the Quality of Working Life. Management and Labour Studies 1996, 21(1): 1-15.

4. INFS. Nutritive value of local foods. Institute of Nutrition and Food Science, University of Dhaka 1986.

5. Ergenç Alev. Ýp Doyumunun Belirleyicileri Olarak Beklenti Algýlama Tutarsýzlýdý ve Çalýpma Deðerleri. Yönetim Psikolojisi Ulusal Simpozyumu (II, 16-19, 11-1991) Ankara: TODAÝE 1982, 309-340 (Türkiye ve Orta Doðu Amme Ýdaresi Enstitüsü Yayýnlarý No: 201)

6. Khaleque A. and Rahman M. A. Perceived Importance of Job Facets and Overall Job Satisfaction of Industrial Workers. Human Relations 1987; 40(7): 401-416.

7. Davis, Keith. Human behaviour at work: Organizational behaviour. 3rd ed. New York: Mc Graw Hill 1988.

8. Lynch B. P. and Verdin J. A. Job Satisfactions in Libraries: Relationships of the Work Itself, Age, Sex Occupational Group, Tenure Supervisory Level, Career Commitment and Library Department. Library Quarterly 1983; 53: 434-447.

9. Wellmaker, Bernand R. The Relations of Perceived Management Systems and Job Satisfaction of Public Librarians. Dissertation Abstracts International 1985; 45: 3471 A.

10. Ghosh S. and Kalra S. K. Perceptual differences in quality of work life factors, Indian Journal of Training and Development 1982; 12 (3 \& 4) : 10-12.

11. Wanjek C. Food at work: Workplace solutions for malnutrition, obesity and chronic diseases. International Labour Office, Geneva, 2005. 